\title{
Presenting complaints and patient volume in an Emergency Department during one year
}

\author{
Rasmus Carter-Storch", Ulrik Frydkjær-Olsen, Christian Backer-Mogensen \\ From 4th Danish Emergency Medicine Conference \\ Roskilde, Denmark. 25-26 November 2011
}

\section{Background}

Emergency departments (EDs) have a different case-mix than traditional medical and surgical departments. Knowledge of what complaints patients present with at EDs and their incidence is needed. Previous studies on ED case-mix have largely focused on the incidence of different diagnoses. This study aims to create a number of categories that cover the majority of presenting complaints and to establish their volume.

\section{Methods}

A retrospective cohort study of all admissions to Kolding ED during one year. The department covers acute medical, surgical, orthopaedic and vascular surgical admissions to the hospital. The data was retrieved from the electronic system Cetrea, where nurses wrote what complaints or tentative diagnoses the patients were presented with by the referring doctor. The authors developed a list of symptoms, and sorted the patients accordingly. The authors each sorted a share of the patients individually, but met several times to adjust the list and unify the sorting. The patients were each assigned to a maximum of two presenting complaints and/or two tentative diagnoses.

\section{Results}

During 2010 10,070 patients were admitted at Kolding ED. $40.5 \%$ of admissions were medical, $26.8 \%$ were surgical, $14.1 \%$ were orthopaedic and $4.0 \%$ were vascular surgical. The patients presented with a total of 11,220 complaints and tentative diagnoses, $74.7 \%$ presented with one or more complaints and $43.5 \%$ presented with one or more tentative diagnoses. These were initially placed in 77 groups of complaints and 44 tentative diagnoses. These groups were aggregated into

\footnotetext{
* Correspondence: rcarterstorch@gmail.com

Emergency department, Kolding Hospital, Denmark
}

31 larger categories comprising $92.6 \%$ of the total number of complaints and tentative diagnoses. The remaining $7.4 \%$ included among others postoperative complications, procedures, various pains and missing information.

\section{Conclusion}

It is possible to create 31 categories that cover the majority of presenting complaints in an ED. If one knew what diagnoses the patients in each category were discharged with, it would possible to create specific "packages" for each category, helping the health personnel to choose e.g. which laboratory tests to order, in order to cover most discharge diagnoses. This is a topic of further studies.

Published: 16 April 2012

doi:10.1186/1757-7241-20-S2-P41

Cite this article as: Carter-Storch et al:: Presenting complaints and patient volume in an Emergency Department during one year.

Scandinavian Journal of Trauma, Resuscitation and Emergency Medicine 2012 20(Suppl 2):P41.

Submit your next manuscript to BioMed Central and take full advantage of:

- Convenient online submission

- Thorough peer review

- No space constraints or color figure charges

- Immediate publication on acceptance

- Inclusion in PubMed, CAS, Scopus and Google Scholar

- Research which is freely available for redistribution 